\title{
RESEARCH INTO THE ADMINISTRATIVE AND TERRITORIAL REFORM
}

\author{
Guna Malinovska ${ }^{1}$, Anda Zvaigzne ${ }^{2}$ \\ ${ }^{1}$ Mg.soc.sc., Rezekne Academy of Technologies, Rezekne, Latvia, \\ e-mail: guna.malinovska@gmail.com \\ 2 Dr.oec. associate professor, leading researcher, Rezekne Academy of Technologies, \\ Rezekne, Latvia, e-mail: Anda.Zvaigzne@rta.lv
}

\begin{abstract}
.
The research aims to examine the theoretical aspects of administrative and territorial reform as well as to identify the attitudes of Latgale region residents to implementing the new administrative and territorial reform.

The following research methods were employed: qualitative content analysis; analysis of legislative enactments and legal documents; a sociological research method - a survey was conducted to identify the opinions and assessments of Latgale residents about the new administrative and territorial reform; descriptive statistics and the graphical method.

The research examined theoretical aspects regarding the division of territory into administrative units as well as the concept and definitions of a municipality as an administrative unit. The research analysed the results of the survey of Latgale region residents and identified the respondents' assessments of implementing the new administrative and territorial reform.
\end{abstract}

Keywords: Administrative Region, Administrative and Territorial Reform, Municipality, County.

JEL code: $H 70, R 58,038$.

Received: 7 July 2021 Revised: 24 July 2021 Accepted: 20 September 2021

Published: 10 December 2021

\section{Introduction}

There are still discussions on the administrative and territorial reform completed in 2009 (Ministry of Environmental Protection and Regional Development of the Republic of Latvia, 2019) (hereinafter the ATR) whether it was carried out at sufficient quality, the goals set were achieved, the municipalities amalgamated were able to fully perform the functions prescribed for them by law etc. The new ATR launched 10 years later (Ministry of Environmental Protection and Regional Development of the Republic of Latvia, 2019) raises even more questions regarding whether it is a new reform or a continuation of a previous reform in order to correct past mistakes and remedy the shortcomings that have emerged.

The research aims to examine the theoretical aspects of administrative and territorial reform as well as to identify the attitudes of Latgale region residents to implementing the new administrative and territorial reform. 
The following specific research tasks were set to achieve the aim of the research:

1. To examine theoretical aspects regarding the division of territory into administrative units.

2. To identify the attitudes of Latgale region residents to implementing the new administrative and territorial reform.

The following hypothesis was put forward: the population has a positive attitude to implementing the new administrative and territorial reform.

The research employed the following methods: qualitative content analysis; analysis of legislative enactments and legal documents; a sociological research method - a survey was conducted to identify the opinions and assessments of Latgale residents about the new administrative and territorial reform. The results of the survey were processed using the statistical software Statistical Package for the Social Sciences and in some cases the data visualization software Excel. The survey was anonymous and all the data obtained were used in an aggregate form. The respondents' profiles were analysed by municipality. Descriptive statistics was used, as most of the data could be expressed through nominal or value scales. Quantitative analysis was also performed using cross-tabulation. The graphical method was employed to graphically visualize the results obtained.

The research examined theoretical aspects regarding the division of territory into administrative units as well as the concept and definitions of a municipality as an administrative unit. It analysed the results of the survey of Latgale region residents and identified the respondents' assessments of implementing the new ATR.

\section{Theoretical aspects regarding the division of territory into administrative territories}

The concept and development of administrative territories have been extensively researched. In Latvia, for example, the above have been researched by I.Vilka (2004) in her doctoral dissertation "Municipal Reforms and Regional Development in Latvia"; E.Vanags (1997) has researched the organization and economies of municipalities, I.Vilka and E.Vanags (2005) have jointly researched the performance and development of municipalities, Z.Rags $(2000,2002)$ has researched the legal aspects of local government activities, Z.Kalninna-Lukaševica (2013) has researched regional development and the planning and assessment thereof, while P. Šknkinkis (1999) examined the administrative territories and compiled (2021) information on the administrative and territorial division of Latvia for the National Encyclopaedia. 
To make a country easier to administer, it is customary to divide its territory into administrative units. The units are administered by local governments that are elected or appointed (Žubule, 2003). The national Law on Administrative Territories and Populated Areas states that "An administrative territory is a territorial unit of Latvia which is administered by a local government within the scope of its competence" (Law on Administrative Territories..., 2020). The Republic of Latvia is divided into the following administrative territories:

1) territories of local governments of State cities;

2) territories of municipality governments (Law on Administrative Territories..., 2020).

The key purpose of administration and governance is to implement purposeful or intentional activities. Administration and governance is a means whereby territorial strategies can be and are implemented. Administrative territories and their structures reflect territorial strategies both directly and indirectly (Škink,kis, 1999). Local self-government is one of the main forms of governance of administrative units of a country. Local selfgovernment administers the residents living in a particular administrative unit of the country, and the activities of its government directly apply to the particular territory of the country - a unit of administrative and territorial division: a city or town, a civil parish, a county, a region, a district, a province etc. (Keišs, Kazinovskis, 2001).

In all countries of the world, local governments function along with the national government and public authorities. They form the basis of any democracy. The better local governments function institutionally, functionally, financially and administratively, the more efficient public administration is implemented in the interests of the population. It is known that daily the population are most closely associated with their local governments (Keišs, Kazinovskis, 2001). Local governments are considered to be the backbone of any democratic state system and the basis of democracy, and it follows that the more developed local governments, the greater democracy exists in the country (Vanags, Vilka, 2005).

In Latvia, the definition of a local government is given by the Law on Local Governments (Law on Local Governments, 1994). In accordance with the provisions of Section 3, Paragraph one of the Law, "A local government is a local administration which, through bodies of representatives elected by citizens - city or municipality council - and authorities and institutions established by them, ensures the performance of the functions prescribed by law, as well as the performance of tasks assigned by Cabinet according to the procedures specified by law, and local government voluntary initiatives, observing the interests of the State and of the residents of the relevant administrative territory" (Law on Local Governments, 1994). 


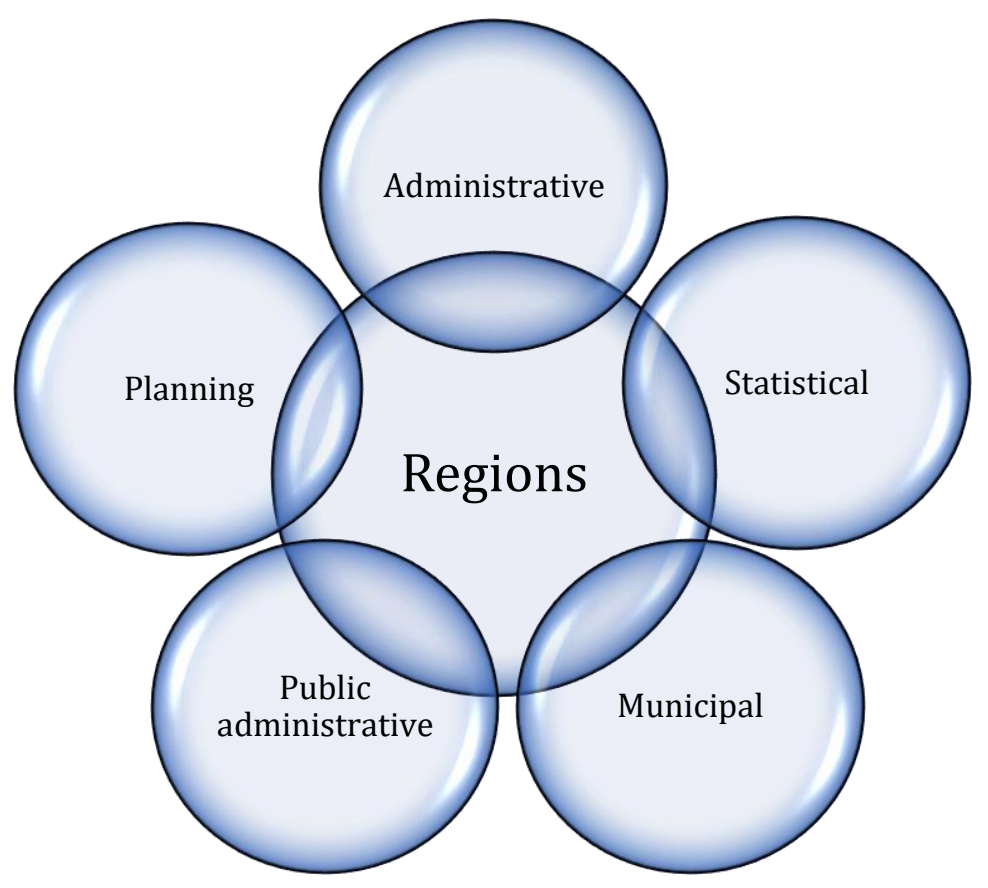

Fig.1 Division of administrative units (authors' construction)

The territory of a country is divided into different administrative and territorial units according to the purpose of use: self-government, statistical measurements at national, regional or local level etc. The territories of the units may also overlap (Keišs, Kazinovskis, 2001). Municipalities could also be divided into urban and rural ones.

Under the public administration system, relations between different levels of state power or legal administrative relations, as well as the implementation of public administration functions are governed by the principles of centralization and decentralization (Jansone, Reinholde, Ulnicāne, 2002). The principle of centralization applies to the system of direct public administration. The mutual relations of public administration institutions are determined based on this principle. The mutual relations are based on a hierarchy: lower-level authorities are hierarchically subordinated to higher-level authorities. Accordingly, each authority has different decision-making powers depending on the powers delegated to the authority. The application of this principle makes sense only if performing a public administration function involves more than one administrative and territorial unit, e.g. several municipalities. Accordingly, the function is performed more cost-effectively and efficiently if it could be performed at national level (Stucka, 2012; Jansone, Reinholde, Ulnicāne, 2002; Hirsch, 1981). Theory defines such a process also as administrative rationalization (Hirsch, 1981).

The principle of decentralization allows the transfer of some functions or their parts to non-hierarchical institutions. Such institutions perform specific 
functions and manage certain administrative units (Benz, Meincke, 2006). Quite often the principle of decentralization is applied to the transfer of competencies of direct public administration organizations to local government institutions, thereby increasing the conditional independence of local governments and their right to decide on issues important to the residents of their territories (Marcou, Wollman, 2009). Decentralization has several advantages: dealing with administrative matters is entrusted to those who are interested in performing such functions; performing decentralized functions is more efficient and cost-effective than fulfilling centralized functions; in the event that some functions are entrusted to the lowest public administration level, the principle of subsidiarity requiring that public services be provided as close as possible to residents must be respected (Stucka, 2012; Marcou, Wollman, 2009).

The above-mentioned principles depend on the level of autonomy of local governments, as well as on the national understanding of possibilities of influencing the local community. Both the principles of centralization and decentralization are applied as well as the principle of subsidiarity is emphasized with regard to the competence of local governments (Stucka, 2012). The principle of subsidiarity plays an important role in the redistribution of areas of responsibility between national and local authorities (Marcou, Wollman, 2009). The principle of subsidiarity is the golden mean between the principles of centralization and decentralization. It is characterized by the distribution of areas of responsibility between different public administration levels (Rodina, 2009). The principle of subsidiarity means that the highest-level public administration may intervene only if the lowest level is unable to perform its functions completely. And it also works the other way around - the highest public administration level is forbidden to intervene in cases in which the lowest public administration level is able to fully perform the functions assigned (Delcamp, 1994). Therefore, the principle of subsidiarity is mostly a matter of the attitude of political administrations and aims to bring decision-making closer to residents, as well as emphasizes the fact that decision-making power is assigned rather than delegated to local governments (Par tiesvedības..., 2009; Delcamp, 1994).

A country developed in a balanced way and governing its administrative units, especially at municipal level, is a complex process. Therefore, different approaches to development need to be applied in each region of the country (Khwela, 2013). Several difficulties are seen in relations between the national and local governments. The way governance mechanisms are distributed determines their importance at national or local level. Too much delegation of authority to one level or another can lead to an unbalanced redistribution of power, which can affect the availability and quality of 
services provided by the national and local governments. Therefore, regardless of the system of public administration the country has centralized or decentralized -, there will be cases in which local governments benefit from it, and there will be cases where local governments do not benefit from it, meaning that the most optimal solutions should always be sought (Jansone, Reinholde, Ulnicāne, 2002; Delcamp, 1994).

\section{Latgale region residents' ratings of and attitudes to the administrative and territorial reform}

A questionnaire was developed to conduct a survey and identify the opinions of Latgale region residents about the new administrative and territorial reform. The survey was conducted from January to March 2021, and 435 respondents were involved in the survey, representing all 21 municipalities of Latgale region. The survey asked closed-ended questions with one-choice and multiple-choice answers to be shown on nominal and interval scales. The survey was conducted online. Invitations to participate in the study were sent to all Latgale region municipalities, educational institutions of all levels and published on social media sites: draugiem.lv and facebook.com. Several municipalities also published the invitation to fill in a questionnaire on their social media pages and thus reached a larger target audience.

The survey included 33 questions on demographics and identified respondent opinions on the current situation and the situation after the ATR, the ATR goals set by the Ministry of Environmental Protection and Regional Development (hereinafter the Ministry), the development of specific areas after the ATR and the impacts of the ATR on the respondents as well as their families and jobs or educational institutions. In the questions in which the respondents expressed their opinions on the value scale, the average rating given by the residents was calculated for each municipality. The survey results were aggregated by municipality in order to identify a connection between the attitudes of residents of a particular municipality to the ATR, its goals and areas of public importance, e.g. education, public transport, health care and safety.

The survey involved 435 respondents, 353 women (81.1\%) and 82 men or $(18.9 \%)$. The most respondents were from the city of Rezekne -61 or $14 \%$ of the total respondents, followed by Dagda municipality with 52 or $12 \%$, whereas the fewest respondents were from Varkava and Zilupe municipalities - three respondents or $0.7 \%$ from each municipality.

As regards the ages of the respondents, the most respondents or 101 were aged 31 to 40 years, and slightly fewer respondents or 97 were aged 51 to 60 years. The number of young respondents aged 21 to 30 years was also 
quite large, 88, and one less or 87 respondents were aged 41 to 50 years. Low response to the survey was among those aged up to 20 years and above 60 years, which allows us to conclude that the ATR was of most interest to working-age individuals.

An analysis of the respondents' occupations reveals that the most respondents or $263(60.5 \%)$ worked and $92(21.2 \%)$ studied and worked at the same time. Only four respondents $(0.9 \%)$ were retired and seven $(1.6 \%)$ were unemployed.

The respondents were asked to give their ratings of several areas of life in which, according to the Ministry (Ministry of Environmental Protection and Regional Development, 2020), improvements are expected. The respondents could give their ratings on a scale of 1 to 5 , where 1 was poor and 5 was good. First, they were asked to rate the development of the municipality where they lived, i.e. before the ATR. Overall, the current situation was rated as poor by $3.45 \%$ respondents, almost poor by $8.97 \%$, average by $36.78 \%$, almost good by $38.85 \%$ and good by $11.95 \%$. The respondents most satisfied with the situation were found in Livani municipality, where the development of the municipality was rated as average by $42.86 \%$, almost good by $28.57 \%$ and good by $28.57 \%$ respondents. The residents of Ilukste, Cibla and Rugaji municipalities were also satisfied with the situation. However, the current development of their municipalities was rated as poor and almost poor by $60 \%$ residents of Varkava municipality and $40 \%$ residents of Aglona municipality. This means that overall the population were satisfied with the current situation.

The respondents' ratings of the situation with regard to the question "What is your rating of the development of the region where you work/study now?" were slightly different. Of the respondents, 3.4\% rated the region where they lived as poor, and only $1.6 \%$ rated the region where they worked/studied as poor. The ratings of the situation as almost poor decreased from $9 \%$ to $7.1 \%$ and as average also decreased from $36.8 \%$ to $32.6 \%$. The ratings of the situation as almost good increased from $36.9 \%$ to $45.7 \%$, while the ratings of the situation as good remained almost unchanged, increasing from $12 \%$ to $12.9 \%$. Accordingly, it could be concluded that the residents rated the current level of development of the municipalities where they worked/studied higher than the level of development of the municipalities where they lived/studied.

The research compared the respondents' ratings of the development of the municipalities before and after the ATR. The ratings of the municipalities where the respondents live after the ATR revealed that the most respondents expected that the situation would change for the worse, as $11.3 \%$ believed that the development of the municipalities would be poor (7.9\%-points more than those rating the situation before the ATR as poor) and $19.1 \%$ almost 
poor (10.1\%-points more). However, $35.9 \%$ respondents admitted that the development of the municipalities would be average, $16 \%$ almost good (decrease by $22.9 \%$ ) and $7.8 \%$ good (decrease by $4.2 \%$ ).

The ratings of the municipalities where the respondents work/study before and after the ATR differed. It could be concluded that the respondents' ratings of the situation after the ATR as poor increased from $1.6 \%$ to $7.6 \%$ and almost poor from $7.1 \%$ to $15.9 \%$. The ratings of the situation after the ATR as average changed only slightly, increasing from $32.6 \%$ to $38.4 \%$, whereas the ratings of almost good decreased from $45.7 \%$ to $28.3 \%$, the ratings of good decreased from 12.9 to $9.9 \%$.

The survey participants had also an opportunity to rate the ATR itself (Fig.2).

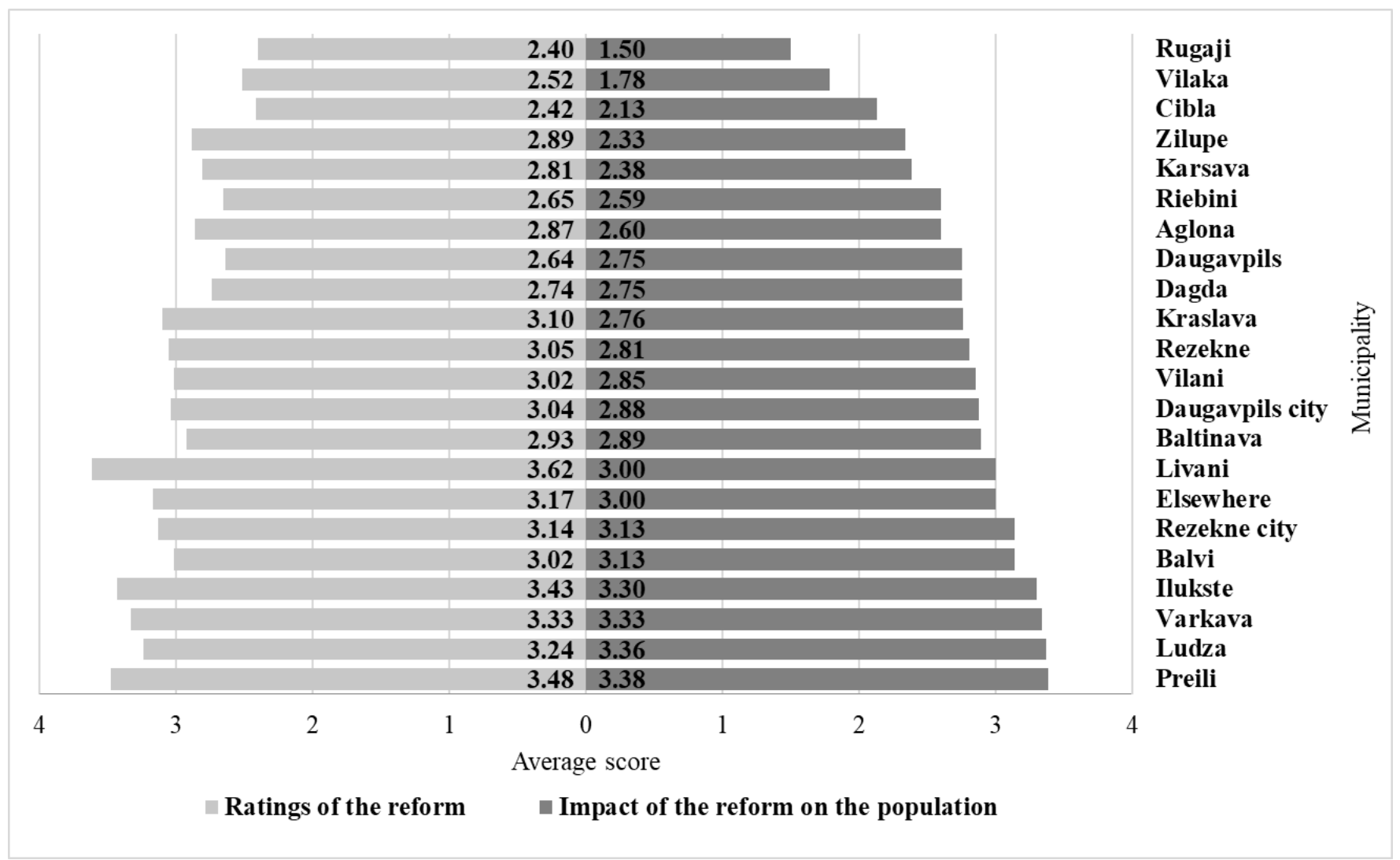

Fig.2 Respondent ratings of the administrative and territorial reform and its impacts on the population (authors' construction)

The residents of Preili, Ludza, Varkava and Ilukste municipalities were the most positive about the ATR, as their average ratings exceeded 3.30 points. The lowest average ratings of the ATR were given by the residents of Rugaji, Vilaka and Cibla municipalities, 1.50, 1.78 and 2.13, respectively. Overall, the residents of Latgale region rated the ATR at 2.85 points, which was slightly below the average. 
A comparison of the residents' ratings of the ATR itself and its impacts on themselves as well as their families and jobs or educational institutions revealed that the list of municipalities whose residents gave more positive ratings slightly differed. Overall, the ATR was positively rated by the residents of Preili, Ludza, Varkava and Ilukste municipalities, while the residents of Livani, Ilukste and Varkava municipalities anticipated a more positive impact of the ATR on the population. In both cases, the residents of Varkava municipality viewed the ATR more positively. However, the residents of the same municipalities - Rugaji, Vilaka and Cibla - gave more negative ratings of the ATR itself and its impacts on the population.

An analysis of the results of the survey allows us to conclude that the population were quite neutral towards the ATR, as evidenced by the overall average ratings of the ATR. The analysis also leads to a conclusion that there are some municipalities whose residents are more pessimistic, e.g. the residents of Cibla, Vilaka and Rugaji municipalities. Overall, however, the respondents from Preili and Livani municipalities were more optimistic. This could be explained by the fact that the small municipalities of Cibla, Vilaka and Rugaji will be amalgamated into other municipalities (Law on Administrative Territories..., 2020), lose their independence, and the centre of the municipality will be further away than before. As regards the positive ratings given by the residents of Preili and Livani municipalities, the residents of these municipalities were generally more optimistic because, as a result of the ATR, the surrounding administrative territories will be amalgamated into these municipalities (Law on Administrative Territories..., 2020). The case of Livani municipality is different (Law on Administrative Territories..., 2020) because the ATR will not affect the municipality at all, and the boundaries of this administrative territory will not be changed.

An analysis of the overall ratings given by the respondents allows us to conclude that the ratings were mediocre. Accordingly, the hypothesis put forward by the research that the population have a positive attitude to the implementation of the new administrative and territorial reform did not prove to be true.

\section{Conclusions}

1. The territory of any country is usually divided into various administrative units, which are administered by a local government. It is elected or appointed, depending on the level or type of administration of the administrative unit.

2. Local self-government is one of the forms of governance of administrative units. This form of governance applies to persons residing in a particular 
administrative unit of the country: a city or town, a civil parish, a county, a region, a district, a province etc.

3. The performance of functions by local governments is very dependent on how the functions are redistributed between the national and local governments or how the areas of responsibility between national and local authorities are distributed.

4. According to the survey, the residents of Latgale region rated the ATR itself and its goals as mediocre. The respondents rated the future impact of the ATR and the availability and quality of services after the ATR as mediocre. This means that, according to the respondents, the availability and quality of services after the ATR is expected to remain at the same level.

5. The residents of small municipalities that will be amalgamated into administrative territories having centres of regional or national significance are generally more pessimistic about the goals of the ATR and its impact on many areas, as well as the reform process itself.

6. The residents of large municipalities, into which the surrounding administrative territories will be amalgamated, rated the ATR, its goals and impacts on the areas of public importance much more positively.

\section{References}

1. Law on Administrative Territories and Populated Areas (10 June 2020). Law of the Republic of Latvia. Retrieved from https://likumi.lv/ta/id/315654-administrativoteritoriju-un-apdzivoto-vietu-likums

2. Benz, A., Meincke, A. (2006). Sub-National Government and Regional Governance in Germany. Hoffmann-Martinot, V., Wollmann, H. (ed.) State and Local Government Reforms in France and Germany. Wiesbaden: VS Verlag für Sozialwissenschaften. Retrieved from https://www.researchgate.net/publication/302163042 SubNational Government and Regional Governance in Germany

3. Delcamp, A. (1994). Definition and Limits of the Principle of Subsidiarity. Local and regional authorities in Europe, No. 55. Retrieved from https://rm.coe.int/1680747fda

4. Hirsch, J. (1981). The apparatus of the state, the reproduction of capital and urban conflicts. Dear, M., Scott, A. J. (Ed.). Urbanization and Urban Planning in Capitalist Society. London: Taylor \& Francis, 589-604. Retrieved from https://www.taylorfrancis.com/chapters/apparatus-state-reproduction-capitalurban-conflicts-joachim-hirsch/e/10.4324/978135106800022?context=ubx\&refId=006e0922-3698-4de2-b903-47b01adb8ad2

5. Jansone D., Reinholde I., Ulnicāne I. (2002). Latvijas publiskā pārvalde. Riga: University of Latvia.

6. Kalniṇa-Lukaševica, Z. (2013). Reǵionu attīstība Latvijā - reǵionu ekonomiskās attīstības plänošanas un novērtēšanas modelis. Doctoral dissertation. Riga: University of Latvia.

7. Keišs, S., Kazinovskis, A. (2001). Reǵionālā administratīvi teritoriālā iedalījuma reformas problēmas Latvijā. Riga: Municipal Affairs Board. 
8. Khwela, M. N. (2013). Local Government and the Fragmented Developmental Mandate: A Case of Offender Rehabilitation in South Africa. Journal of African \& Asian Local Government Studies, No. 2. Retrieved from https://www.semanticscholar.org/paper/Local-Government-and-the-FragmentedDevelopmental-A-Khwela/a28e3282164ab2d54eb807ac188ec9ab13a5f56f\#citingpapers

9. Ministry of Environmental Protection and Regional Development of the Republic of Latvia (5 February 2019). Informatīvais zinojums "Par turpmāko rīcību administratìvi teritoriālās reformas pabeigšanai". Draft legal acts of the Cabinet of the Republic of Latvia. Retrieved from http://tap.mk.gov.lv/lv/mk/tap/?pid=40469036\&mode=mk\&date=2019-02-05,

10. Ministry of Environmental Protection and Regional Development of the Republic of Latvia (2020). Administratīi teritoriālā reforma. Retrieved from http://varam.gov.lv/lat/administrativi teritoriala reforma/

11. Marcou, G., Wollman, H. (2009). Europe. Adib, M., Brillantes, A. B. et al. (Ed.). Decentralization and local democracy in the world: First Global Report by United Cities and Local Government. Barcelona: United Cities and Local Government. Retrieved from http://hdl.handle.net/10986/2609

12. Law on Local Governments (9 June 1994). Law of the Republic of Latvia. Retrieved from https://likumi.lv/ta/id/57255-par-pasvaldibam

13. Par tiesvedības izbeigšanu lietā Nr.2008-08-0306 (23 January 2009). Decision of the Constitutional Court of the Republic of Latvia. Retrieved from https://likumi.lv/ta/id/186836-par-tiesvedibas-izbeigsanu-lieta-nr-2008-08-0306

14. Rags, Z. (2000). Pašvaldības un to darbības tiesiskais pamats demokrātiskā valstī. Riga: State Police College.

15. Rags, Z. (2002). Latvijas Republikas Pašvaldību tiesības. Riga: State Police College.

16. Rodinna, A. (2009). Konstitucionālās sūdzības teorija un prakse. Riga: Latvijas Vēstnesis.

17. Stucka, A. (2012). Latvijas pašvaldību sistēmas pilnveidošanas aktuālie valststiesību jautājumi. Doctoral dissertation. Riga: University of Latvia.

18. Šķin,ksis, P. (1999). Teritorijas un teritoriālās stratēǵijas Latvijā. Doctoral dissertation. Riga: University of Latvia.

19. Šķiņķis, P. (2021). Administratīvi teritoriālais iedalījums Latvijā. Retrieved from https://enciklopedija.lv/skirklis/22981-administrat\%C4\%ABviteritori\%C4\%81lais-iedal\%C4\%ABjums-Latvij\%C4\%81

20. Vanags, E. (1997). Pašvaldību organizācija un ekonomika. Riga: University of Latvia.

21. Vanags, E., Vilka, I. (2005). Pašvaldību darbība un attīstība. Riga: Academic Press of the University of Latvia.

22. Vilka, I. (2004). Pašvaldību reformas un reǵionālā attīstība Latvijā. Doctoral dissertation. Riga: University of Latvia.

23. Žubule, E. (2003). Pašvaldības un to finanses Latvijā. Rezekne: RA Publisher. 